\title{
PERAN KOMUNITAS DALAM PENANGANAN TEMUAN BARU PRASASTI (STUDI KASUS KOMUNITAS KANDANG KEBO)
}

\section{COMMUNITY'S INVOLVEMENT IN HANDLING NEWLY FOUND INCRIPTIONS (KANDANG KEBO COMMUNITY CASE STUDY)}

\author{
Goenawan A. Sambodo ${ }^{1}$, Maria Tri Widayati², Hery S. Purnawali ${ }^{3}$ \\ Sarjana Arkeologi, Politeknik "API" Yogyakarta, \\ Ikatan Ahli Perencanaan Indonesia (IAP) \\ sekarpudak@yahoo.co.uk
}

\begin{abstract}
The aim of this study is to identify and analyze the efforts of the Kandang Kebo Community in handling new found inscriptions. The method used is descriptivequalitative, combined with inductive reasoning. Structural analytic, especially Internal Criticism (transliteration, translation and interpretation) is also applied to analyse the new found inscription. Information for this study were collected from the members of Kandang Kebo community, stakeholders, and local community. Data collection were done by observation, literature study, interviews, and documentation. This study found that community which participate in maintaining cultural heritage objects is a provision in the Cultural Heritage Act no. 11 of 2010. Kandang Kebo as a society's community has been trying to apply this Act. The using of social media becomes one of the methods, with its quick and easy way; it makes new artifacts discovery easier to be known by others. Kandang Kebo then proceed this news to the office of BPCB. There are some inscriptions that are successfully saved and read by Kandang Kebo, followed by positive responses from the government.
\end{abstract}

Keywords: Community; Inscription; Klaten; Boyolali

\section{ABSTRAK}

Penelitian ini bertujuan untuk mengidentifikasi dan menganalisis upaya yang dapat dilakukan untuk melindungi temuan prasasti baru, serta mengidentifikasi peran Komunitas Kandang Kebo dalam penanganan temuan prasasti-prasasti baru. Metode penelitian yang digunakan adalah deskriptif kualitatif. Analisis prasasti baru yang ditemukan menggunakan analisis struktural, yaitu melakukan kritik intern yang berupa transliterasi atau alih bahasa pada pesan atau isi prasasti yang menghasilkan penafsiran. Informan terdiri dari anggota komunitas, pemangku kepentingan, dan masyarakat setempat. Pengumpulan data dilakukan dengan cara observasi, studi pustaka, wawancara mendalam, dan dokumentasi. Penelitian ini menemukan bahwa keterlibatan masyarakat dalam turut serta menjaga benda cagar budaya merupakan ketentuan dalam UU Cagar Budaya no. 11 Tahun 2010. Kandang Kebo sebagai komunitas yang ada di masyarakat mencoba memaknai hal itu dengan caranya sendiri, yaitu menggunakan media sosial untuk mencari informasi mengenai temuan benda cagar budaya baru. Sifat media sosial yang cepat membuat beberapa temuan baru yang ada di masyarakat dapat segera diketahui. Kandang Kebo kemudian mencoba meneruskan berita tersebut kepada pihak terkait, misalnya BPCB. Melalui aktivitas tersebut, telah ada beberapa prasasti yang dapat diselamatkan dan dibaca oleh Komunitas Kandang Kebo dan mendapatkan tanggapan segera dan sangat baik dari dinas terkait.

Kata kunci: Komunitas; Prasasti; Klaten; Boyolali

Artikel Masuk $\quad$ : 22-03-2019

Artikel Diterima $\quad$ : 18-06-2019 


\section{PENDAHULUAN}

Keterbatasan instansi terkait dalam merespon informasi mengenai temuan-temuan cagar budaya atau diduga cagar budaya yang salah satunya berupa prasasti baru, menyebabkan munculnya berbagai komunitas pelestari cagar budaya. Komunitas-komunitas pelestari cagar budaya dan pecinta sejarah banyak berdiri dengan kegiatan utamanya melakukan penyelamatan dan pelestarian cagar budaya. Peran aktif komunitas dalam menyikapi pemajuan kebudayaan Indonesia ditandai dengan penyelenggaraan Kongres Nasional Komunitas Sejarah di Kabupaten Kediri, Jawa Timur pada tanggal 26-28 Oktober 2018, yang dihadiri oleh 80 komunitas se Indonesia. ${ }^{1}$

Kertajaya (2008, hlm. 21) seorang ahli di bidang pemasaran mendefinisikan bahwa komunitas adalah sekelompok orang yang saling peduli satu sama lain lebih dari yang seharusnya, dan di dalam sebuah komunitas terjadi relasi pribadi yang erat antar anggota komunitas tersebut karena adanya kesamaan interest dan values. Sementara menurut Crow dan Allan (1994, hlm. 98) seorang professor sosiologi dan politik, komunitas dapat terbagi menjadi dua komponen yaitu berdasarkan lokasi dan berdasarkan minat. Hal itu dapat dilihat pada komunitaskomunitas yang ada di sekitar yang terbentuk berdasarkan kesamaan yang dimiliki. Vanina Delobelle (2008), menyebutkan bahwa komunitas adalah group beberapa orang yang berbagi minat yang sama, yang terbentuk oleh 4 faktor, yaitu komunikasi dan keinginan berbagi, tempat yang disepakati bersama untuk bertemu, ritual dan kebiasaan, serta influencer yaitu merintis sesuatu hal dan anggota terlibat di dalamnya. Lebih lanjut Vanina juga menjelaskan bahwa komunitas mempunyai beberapa aturan sendiri, yaitu: a. Saling berbagi; $b$. Komunikasi; c. Kejujuran; d.Transparansi; dan e. Partisipasi. Berdasar definisidefinisi di atas, maka dalam penelitian ini yang dimaksud Komunitas adalah sekelompok orang dengan latar belakang berbeda namun memiliki minat yang sama, saling berkomunikasi dan berbagi, memiliki tempat untuk saling bertemu, kebiasaan, serta para anggota terlibat di dalamnya.

Dalam kegiatan komunitas, masing-masing anggota memiliki peran berbeda. Hal itu karena kondisi setiap manusia yang berbeda memunculkan suatu pembagian peran dari masing-masing individu (Sarwono, 2015, hlm. 215). Peran menurut Soekanto (2002, hlm. 243), adalah aspek dinamis kedudukan (status), apabila seseorang melaksanakan hak dan kewajibannya sesuai dengan kedudukannya, maka ia menjalankan suatu peranan. Sementara di dalam Kamus Umum Bahasa Indonesia, peran adalah sesuatu yang jadi bagian atau yang memegang pimpinan yang terutama (Poerwadarminto, 1984, hlm. 735). Berdasar berbagai pendapat tersebut, peran dalam konteks peran komunitas adalah suatu fungsi yang dibawakan komunitas ketika menduduki suatu posisi dalam struktur sosial tertentu. Peran Komunitas merupakan aspek dinamis kedudukan (status), apabila komunitas melaksanakan hak dan kewajibannya sesuai dengan kedudukannya.

Salah satu komunitas sejarah yang berkedudukan di Yogyakarta adalah Komunitas Kandang Kebo. Komunitas ini bergerak dibidang pelestarian warisan

${ }^{1}$ https:// kebudayaan.kemdikbud.go.id/ditsejarah/ kongres-nasional-komunitas-sejarah-dan-geliat-ekosistembudaya-kampung-madu/ 
budaya dengan berbagai kegiatan. Salah satu kegiatannya berupa blusukan, yaitu kegiatan melakukan perjalanan dari satu tempat ke tempat lain untuk melakukan pendataan terhadap cagar budaya atau diduga cagar budaya yang sebagian besar belum terdata oleh instansi terkait. Kenyataannya, jumlah situs cagar budaya di wilayah DIY ini yang sudah masuk cagar budaya masih lebih sedikit apabila dibandingkan dengan jumlah situs yang belum dilindungi. Oleh karena itu melalui kegiatannya, Komunitas Kandang kebo berperan aktif membantu instansi terkait untuk melakukan pendataan secara sukarela, agar cagar budaya maupun diduga cagar budaya bisa terselamatkan dan terlindungi keberadaannya.

Salah satu yang menjadi perhatian Komunitas Kandang Kebo adalah penemuan prasasti baru oleh masyarakat. Saat mendengar ada temuan prasasti baru, anggota komunitas segera mencari informasi dan berusaha untuk menuju lokasi. Apabila informasi akurat, maka segera memberitahu pihak terkait mengenai temuan tersebut. Selain itu, karena Komunitas Kandang Kebo memiliki anggota yang bisa membaca prasasti sekaligus menterjemahkannya, maka prasasti temuan baru tersebut akan langsung dibaca dan diterjemahkan, kemudian sekaligus dilakukan analisis.

Prasasti merupakan sumber primer dalam penyusunan sejarah, sehingga keberadaannya sangat penting. Selain itu dari nilai ekonominya, prasasti memiliki nilai jual sangat tinggi, sehingga keberadaan prasasti sangat rawan dari praktek pencurian untuk diperjualbelikan. Berita hilangnya prasasti pernah terjadi di Lumajang pada tahun 2014 berupa lima Prasati Pasrujambe yang merupakan peninggalan kerajaan Majapahit Timur di Lumajang. Prasasti ini awalnya disimpan di Dinas Pendidikan dan Kebudayaan kabupaten Lumajang. Berita tersebut memicu Komunitas pecinta sejarah di Lumajang yang menamakan diri Masyarakat Peduli Peninggalan Majapahit Timur (selanjutnya disingkat MPPM) bersama elemen masyarakat lainnya di Lumajang bertindak menuntut pemerintah untuk membentuk tim investigasi atas hilangnya prasasti bersejarah tersebut (Indrawan, A. \& Ichsan A.S., 2014). Hasil penyelidikan yang kemudian dilakukan menemukan bahwa prasasti yang disinyalir hilang ternyata disimpan di Museum Negeri Mpu Tantular. Hal ini menunjukkan kurangnya komunikasi antara pemerintah dan masyarakat.

Keberadaan prasasti yang sangat penting bagi penyusunan sejarah membutuhkan penanganan yang hati-hati, karena rata-rata usia yang sudah sangat tua, baik itu prasasti batu yang sangat berpotensi aus, maupun prasasti logam yang berpotensi mengalami korosi. Sampai saat ini prasasti tertua ditemukan di Kalimantan Timur yang dikenal dengan Prasasti Yūpa, berupa tiang batu yang berdasar paleografis berasal dari abad ke-5 Masehi dan dituliskan dalam Bahasa Sanskerta. Selain prasasti Yupa, di Kalimantan juga ditemukan prasasti lain, yaitu Prasasti di kampung Pahat Sanggau dan prasasti di pinggir Sungai Sekayan Sanggau. Diperkirakan usia prasasti lebih muda dari Prasasti Yupa (DITPCBM, 2015). Temuan prasasti-prasasti tertua di Kalimantan tersebut, tidak berarti bahwa di Kalimantan banyak ditemukan prasasti, karena berdasar kajian, jumlah tinggalan prasasti terbanyak berada di Pulau Jawa dengan jumlah sebanyak 386 kelompok prasasti (Nastiti, 2009, hlm. 381-387). Jumlah prasasti tersebut merupakan prasasti yang sudah terdata dan disimpan di museum maupun instansi terkait. Sejalan dengan berkembangnya waktu, banyak prasasti 
baru ditemukan kembali. Penemuan kembali prasasti biasanya secara tidak sengaja oleh masyarakat awam. Hal itu menyebabkan rawannya prasasti yang ditemukan di ambil atau dibeli seseorang sebelum dinas terkait melakukan pendataan. Lambannya pendataan tersebut disebabkan terbatasnya jumlah sumber daya manusia yang berwenang melakukan pendataan cagar budaya.

Berdasar uraian tersebut nampak banyak permasalahan yang dihadapi dalam melaksanakan perlindungan dan pelestarian cagar budaya. Oleh karena itu untuk memberikan arah dalam penelitian ini, dirumuskan masalah yang akan dijawab dalam penelitian, yaitu:

1. Bagaimana peran Komunitas dalam penanganan temuan prasasti-prasasti baru?

2. Bagaimana analisis prasasti baru yang ditemukan?

Berdasar rumusan masalah yang ada, maka tujuan dari penelitian ini adalah mengetahui peran Komunitas Kandang Kebo dalam mengidentifikasi dan menganalis prasasti baru yang ditemukan.

\section{METODE}

Penelitian ini menggunakan pendekatan kualitatif yaitu metode penelitian yang digunakan untuk mendeskripsikan dan menganalisa fenomena, peristiwa, aktivitas sosial, sikap, kepercayaan, persepsi, pemikiran orang baik secara individual maupun kelompok (Sukmadinata, 2007, hlm. 60). Jenis penelitian yang dipilih adalah jenis penelitian deskriptif, meliputi potret subjek, rekonstruksi dialog, deskripsi keadaan fisik, struktur tentang tempat, dan barang-barang lain yang ada di sekitarnya, serta catatan tentang berbagai peristiwa khusus (Sutopo, 2002, hlm. 74).

Peneliti mengumpulkan data yang berasal dari aktifitas Komunitas Kandang Kebo. Data primer berupa informasi tentang kegiatan Komunitas Kandang Kebo khususnya dalam penanganan temuan prasasti baru. Selain itu data primer juga berupa prasasti yang baru ditemukan dan belum dibaca sebelumnya. Fakta atau gejala dari data digambarkan dengan mendeskripsikan isi prasasti dengan melakukan analisis terlebih dahulu, untuk mengetahui maksud dari isi prasasti tersebut. Tahapan penelitian dimulai dari alih aksara prasasti, alih bahasa, dan kemudian dilakukan analisis. Upaya yang dilakukan agar tujuan penelitian tercapai, digunakan beberapa teknik pengumpulan data sebagai berikut.

\section{Observasi}

Dalam penelitian ini dilakukan pengamatan terhadap aktivitas Komunitas Kandang Kebo saat melihat lokasi dan lingkungan temuan prasasti, pembacaan prasasti, dan kegiatan analisisnya. Dalam melakukan observasi, peneliti datang ke lokasi penelitian untuk melihat dan mengidentifikasi secara langsung data yang dibutuhkan (Audifax, 2008, hlm. 73, dan Nasution, 1992, hlm. $56-58)$. 


\section{Wawancara Mendalam}

Dalam melakukan wawancara terhadap anggota komunitas Kandang Kebo yang menemukan prasasti atau informasi tentang prasasti baru, serta terhadap anggota yang terlibat dalam menterjemahkan maupun menganalisis temuan prasasti tersebut, digunakan panduan wawancara berupa garis besar tema yang akan ditanyakan. Tujuan wawancara adalah untuk membawa beberapa isu pendahuluan ke permukaan sehingga peneliti dapat menentukan variabel yang akan digunakan dalam penelitian lebih mendalam (Sekaran dan Bougie, 2010, hlm. 186). Variabel tersebut antara lain profil dan kegiatan Komunitas Kandang Kebo. Peneliti tidak menggunakan pedoman wawancara yang telah tersusun secara sistematis dan lengkap untuk pengumpulan data, tetapi hanya menggunakan pedoman berupa garis-garis besar permasalahan yang akan diteliti (Sugiyono, 2005, hlm. 74). Wawancara mendalam selain dilakukan terhadap beberapa anggota Komunitas Kandang Kebo, juga dilakukan kepada masyarakat setempat di sekitar lokasi temuan prasasti.

Informan dipilih sendiri oleh peneliti dengan menggunakan teknik snowball purposive sampling, yaitu peneliti menentukan sendiri/memilih orang tertentu yang dipertimbangkan akan memberikan data yang diperlukan (sering disebut sebagai informan kunci/key informan). Selanjutnya, berdasarkan data atau informasi yang diperoleh dari informan sebelumnya, peneliti menetapkan informan lain yang dipertimbangkan akan memberikan data lebih lengkap (Sugiyono, 2005, hlm. 54-55). Demikian seterusnya sampai informasi yang dibutuhkan mengenai profi, kegiatan, dan peran Komunitas Kandang Kebo dalam penanganan temuan prasasti baru terpenuhi. Pemilihan teknik snowball sampling dilakukan karena informan yang dibutuhkan adalah informan yang mengetahui secara mendetail tentang tema yang ditanyakan.

\section{Dokumentasi}

Melalui studi dokumentasi, data yang didapatkan berupa data sekunder (Sugiyono, 2005, hlm. 82-83). Dalam penelitian ini studi dokumentasi dilakukan untuk memperoleh informasi tentang aktivitas Komunitas Kandang kebo dalam penanganan temuan prasasti dengan melihat foto maupun laporan kegiatan. Selain itu juga hasil pembacaan maupun analisis temuan prasasti baru yang sudah dilakukan oleh Komunitas Kandang Kebo.

Proses analisis data yang digunakan dalam penelitian ini berdasarkan pada pendapat Miles dan Huberman (1992, hlm. 19-20) yang menyatakan bahwa analisis terdiri dari tiga alur kegiatan yang terjadi secara bersamaan, yaitu reduksi data, penyajian data, dan penarikan kesimpulan/verifikasi. Langkah dalam penelitian ini adalah pertama melakukan pendokumentasian, kedua melakukan inventarisasi terhadap sumber daya, ketiga dilakukan penilaian terhadap sumber daya yang sudah diinventarisasi, dan keempat dilakukan pengkajian yang mendalam, penginterpretasian, dan penentuan strategi. 


\section{HASIL PENELITIAN DAN PEMBAHASAN}

Berkaitan dengan peran komunitas dalam penanganan prasasti baru sebagai benda cagar budaya, dalam Undang-Undang Cagar Budaya Nomor 11 tahun 2010 tentang Benda Cagar Budaya disebutkan bahwa setiap orang, seluruh elemen masyarakat, maupun pemerintah wajib terlibat dalam pelestarian cagar budaya tersebut. Pelestarian adalah upaya dinamis untuk mempertahankan keberadaan Cagar Budaya dan nilainya dengan cara melindungi, mengembangkan, dan memanfaatkannya. Kemudian berkaitan dengan peran komunitas, pada Ayat 35 disebutkan bahwa setiap orang adalah perseorangan, kelompok orang, masyarakat, badan usaha berbadan hukum,dan/atau badan usaha bukan berbadan hukum. Pada Pasal 29 ayat 2 disebutkan bahwa setiap orang dapat berpartisipasi dalam melakukan pendaftaran terhadap benda, bangunan, struktur, dan lokasi yang diduga sebagai Cagar Budaya meskipun tidak memiliki atau menguasainya. Pasal 56 Setiap orang dapat berperan serta melakukan Pelindungan Cagar Budaya. Pasal 63 Masyarakat dapat berperan serta melakukan Pengamanan Cagar Budaya. Berdasarkan Undang-Undang Cagar Budaya Nomor 11 tahun 2010 tersebut jelas bahwa semua orang tanpa kecuali harus turut serta dalam kegiatan pelestarian maupun perlindungan cagar budaya.

Perbedaan tanggapan langsung (perception) di kalangan masyarakat tentang pelestarian cagar budaya perlu dicari solusi agar masyarakat dapat memahami tentang pentingnya pelestarian cagar budaya. Sosialisasi dan publikasi tentang pentingnya pelestarian cagar budaya kepada masyarakat (dan bahkan para pemangku kebijakan) perlu dilakukan secara terpadu dan terus menerus serta dengan pelibatan seluruh unsur masyarakat. Apabila masyarakat mengenal dengan baik nilai penting cagar budaya, diharapkan dapat menumbuhkan rasa memiliki sehingga mau berperan serta dalam pelestariannya. Cagar budaya sebagai bukti nyata dari peradaban suatu masyarakat merupakan ingatan bersama (collective memorie) dari masyakarat yang bersangkutan. Seringkali terdapat hubungan batin yang erat antara masyarakat dan cagar budaya disekitarnya, sehingga cagar budaya dapat dijadikan sebagai lambang keberadaan (existensi) dan simbol identitas. Nilai penting kedua hal itu (lambang keberadaan dan simbol identitas) tidak akan dapat diketahui tanpa adanya usaha untuk menemukannya. Penemuan kembali identitas dan keberadaan bersama masyarakat yang terkandung dalam sebuah benda cagar budaya diharapkan dapat memperkuat kerukunan dalam kehidupan bermasyarakat karena merasa memiliki ingatan bersama yang sama. Kenangan bersama terhadap sebuah benda cagar budaya ini dapat digunakan sebagai penguat identitas budaya masyarakat yang diharapkan dapat menjadi penguat persatuan dan kerukunan hidup bermasyarakat.

Komunitas Kandang Kebo sebagai bagian dari masyarakat turut serta memberitakan, mensosialisasikan, dan berkoordinasi dengan pihak pihak terkait, dalam hal ini dinas kebudayaan kabupaten/kota atau Balai Pelestarian Cagar Budaya (BPCB) Jawa Tengah dan DIY, terhadap temuan benda cagar budaya, secara khusus berupa prasasti. Biasanya temuan-temuan prasasti baru diberitakan lewat percakapan group media sosial yang sebelumnya belum pernah dibaca.

Berdasar pengamatan, diketahui bahwa Komunitas Kandang Kebo merupakan sebuah wadah berkumpulnya beberapa orang yang memiliki latar belakang berbeda, namun memiliki kesamaan pada minat dan kecintaan terhadap 
cagar budaya maupun diduga cagar budaya. Komunitas Kandang Kebo, merupakan sebuah komunitas yang peduli pada tinggalan cagar budaya. Mereka mencoba menularkan kepedulian terhadap warisan budaya baik yang sudah berpredikat sebagai cagar budaya maupun yang masih diduga sebagai benda cagar budaya di kalangan masyarakat.

Kegiatan yang dilakukan oleh Komunitas Kandang Kebo cukup beragam, baik secara formal seperti menyelenggarakan kegiatan ilmiah berupa sarasehan, workshop, pelatihan, diskusi, dan sejenisnya setiap 3 bulan sekali dengan menghadirkan narasumber yang kompeten di bidangnya. Kegiatan ilmiah biasanya dihadiri oleh sekitar 100 peserta. Kegiatan juga dilakukan secara tidak formal ketika blusukan di tempat yang menarik perhatian mereka sembari berbincang dengan para penduduk. Mereka melakukan kunjungan ke situs-situs marginal sekaligus mengedukasi masyarakat sekitar situs tentang pentingnya penyelamatan situs.

Dalam kegiatannya, Komunitas Kandang Kebo didukung oleh sumber daya manusia yang kompeten di bidangnya. Berdasar data yang dimiliki Komunitas Kandang Kebo, beberapa anggota merupakan lulusan S1 Arkeologi dengan spesialisasi Arkeologi Klasik dan Epigrafi. Terdapat juga anggota yang memiliki pendidikan S2 Antropologi dan S3 Kajian Pariwisata. Sebagian yang lain lulusan SMA dan S1 dari berbagai bidang ilmu.

Kegiatan Komunitas Kandang Kebo banyak memanfaatkan berbagai media sosial untuk melakukan persuasi kepada masyarakat luas. Tujuan utama pemanfaatan media adalah mengajak pemuda dan masyarakat umum untuk ikut bergabung dalam kegiatannya, mengingat media sosial adalah media popular yang sehari-hari digunakan terutama oleh kaum muda untuk sekedar mencari informasi, update status, atau melakukan aksi narsisme. Kelebihan media sosial sebagai ruang berbagi inilah yang dimanfaatkan oleh Komunitas Kandang Kebo. Dengan memanfaatkan media online, semua kegiatan yang dilakukan oleh komunitas langsung tersebar luas di dunia maya, yang tentunya mempermudah komunitas dalam mempersuasi masyarakat serta menyebarluaskan informasi yang terkait dengan komunitas mereka. Berdasar pada berbagai media yang digunakan serta konten dari media menunjukkan Komunitas Kandang Kebo adalah suatu organisasi sosial yang aktif dalam media sosial. Salah satu aktivitas Komunitas Kandang Kebo adalah Web yang dimiliki yaitu https://kandangkebo.org, group Faceebook Kandang Kebo Menapak Jejak Sang Leluhur Nusantara, dan IG komunitas kandang kebo.

Di lain pihak, pemerintah dalam hal ini dinas terkait dengan benda budaya tersebut, diantaranya dinas kebudayaan, baik kabupaten/kota maupun propinsi, dan secara lebih khusus adalah Balai Pelestarian Cagar Budaya (BPCB), seringkali tidak dapat secara terus menerus melakukan pemantauan terhadap benda-benda cagar budaya yang tersebar luas di area kerja mereka. Beberapa kali terjadi bahwa temuan suatu cagar budaya penting berdasar laporan dari masyarakat dalam hal ini komunitas yang peduli dengan hal tersebut. Hal itu tentunya menjadi sebuah kerjasama yang baik bagi kedua belah pihak. Di satu sisi kesenangan dan kepedulian para anggota komunitas dapat terwujud, di sisi lain pengawasan atau bahkan temuan-temuan baru dapat segera ditindak lanjuti oleh pihak dinas terkait sehingga benda tersebut dapat segera diperlakukan sebagaimana mestinya. 
Arah dan ukuran keberhasilan itu akan sangat ditentukan seberapa besar irisan sinergi dapat dilakukan oleh para pihak pelaku yang peduli akan tinggalan budaya tersebut. Kenyataan menegaskan bahwa hingga kini tidak mungkin semua yang tercantum dalam rencana pelestarian dapat diwujudkan oleh pemerintah secara sepihak. Oleh karena itu terdapat kebutuhan mutlak untuk mengembangkan model pelestarian yang melibatkan para pemangku kepentingan lain yang saling menguntungkan dan memberikan manfaat sebesarbesarnya bagi masyarakat luas.

Penyelarasan antara kesenangan dan hobi tanpa harus bersinggungan dengan hukum sehubungan dengan aturan aturan yang ada di dalam UndangUndang Cagar Budaya Nomor 11 tahun 2010, maka komunitas Kandang Kebo merasa perlu untuk selalu menggandeng pihak pihak terkait yang berhubungan dengan cagar budaya. Penelitian ini menemukan bahwa bahwa kerjasama yang baik antara masyarakat dalam hal ini komunitas Kandang Kebo dengan pihak pihak pemangku kepentingan telah dapat berjalan dengan baik. Beberapa kali temuan temuan benda cagar budaya -secara khusus prasasti- di beberapa tempat dapat berjalan dengan baik karena adanya kerjasama ini. Pelaporan kepada dinas terkait dalam hal ini BPCB Jateng dan DIY, telah dilakukan setelah para anggota komunitas melihat atau merasa bahwa sebuah benda cagar budaya perlu didata dan diperlakukan sebagaimana mestinya.

Beberapa kegiatan Komunitas Kandang Kebo yang telah dilakukan diantaranya adalah penemuan dan pembacaan prasasti baru yang ditemukan di tengah masyarakat. Prasasti tidak hanya sebagai media penyampai pesan tekstual, karena pada hakikatnya merupakan produk bendawi dari kegiatan manusia masa lampau yang masuk dalam kategori artefak (Kusumohartono,1994, hlm. 17).

Berdasarkan gagasan tersebut, prasasti dapat diartikan sebagai salah satu artefak berbentuk keputusan resmi yang dikeluarkan oleh penguasa atau raja yang berisi pengumuman, peraturan dan perintah. Keberadaan prasasti menjadi rujukan utama ketika dilakukan penyusunan sejarah, sehingga keselamatan prasasti menjadi hal mutlak bagi pembuktian kesejarahan.

Penemuan sebuah prasasti baru biasanya diawali oleh masyarakat yang kemudian menyampaikannya kepada salah satu anggota Komunitas Kandang Kebo. Melalui alat komunikasi dan media WhatsApp, informasi kemudian diteruskan ke WhatsApp Group Kandang Kebo. Isi berita biasanya berupa kiriman foto dan lokasi temuan. Hal itu seperti yang terjadi beberapa waktu yang lalu ketika pesan bergambar dari seorang teman anggota komunitas Kandang Kebo, mengabarkan adanya sebuah lingga bertulis dengan pahatan huruf yang masih tampak jelas. Setelah saling bertukar keterangan tentang gambar itu, maka diputuskan untuk melihat langsung lingga bertulis itu. Pada lain kesempatan dengan model berbagi keterangan yang hampir sama, diketahui pula adanya beberapa temuan prasasti lain di banyak tempat di sekitar tempat tinggal para anggota komunitas.

Berikut beberapa prasasti yang bisa terselamatkan dan akhirnya terbaca dan dianalisa oleh Komunitas Kandang Kebo.Dalam melakukan analisa terhadap sebuah prasasti, baru, Komunitas Kandang kebo menggunakan analisis struktural, yaitu melakukan kritik intern yang berupa transliterasi atau alih bahasa pada pesan atau isi prasasti yang menghasilkan penafsiran berupa keterangan yang 
berhubungan dengan aspek ekonomi, politik, agama, birokrasi, dan sebagainya pada masa lampau. Analisis ini adalah cara umum yang digunakan kalangan epigraf untuk mendapatkan interpretasi atas isi prasasti (Dwiyanto, 1993, hlm. 7).

\section{Temuan Prasasti Añgĕhan II.}

Informasi mengenai temuan prasasti ini didapat oleh Komunitas Kandang Kebo dari anggota yang sedang blusukan, yang kemudian diinformasikan melalui pesan WhatsApp Group Kandang Kebo. Berdasar informasi tersebut, kemudian beberapa anggota Komunitas mendatangi lokasi dan menginformasikan temuan ke BPCB Jawa Tengah. Salah satu anggota Komunitas yang mempunyai latar belakang pendidikan Arkeologi dengan spesialisasi epigrafi kemudian membaca isi prasasti tersebut.

Berdasar pendataan yang dilakukan oleh Komunitas Kandang Kebo, diketahui bahwa prasasti ini berbentuk lingga, berada di salah satu rumah penduduk di daerah Klaten, Jawa Tengah. Prasasti itu ditemukan ketika sang kakek pemilik lahan, akan membuat pondasi untuk pagar tembok pembatas halaman. Batu prasasti ini belum pernah diteliti atau dibaca oleh dinas terkait ataupun peneliti yang berkompeten.

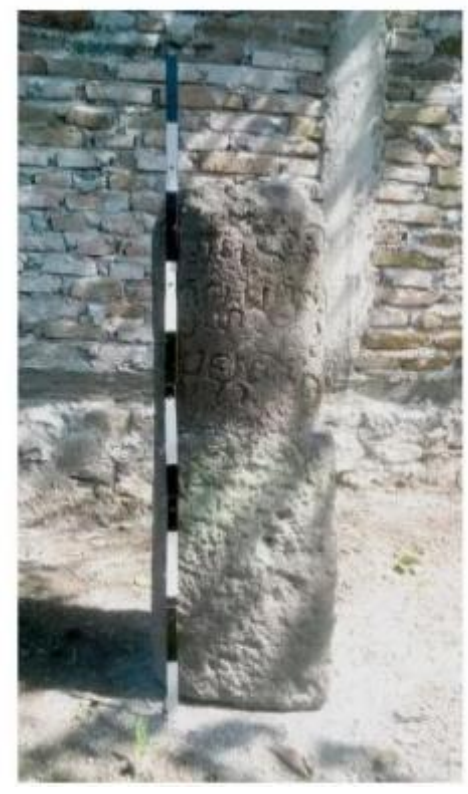

Gambar 1. Prasasti Angehan II (Sumber: Goenawan A.Sambodo, Foto Tahun 2018)

Lingga bertulis berukuran tinggi $82 \mathrm{~cm}$, lingkar bulatan atau silinder $90 \mathrm{~cm}$, kaki berbentuk kotak $28 \mathrm{~cm}$, dengan silinder tinggi bertulisan $38 \mathrm{~cm}$. Prasasti tersebut kemudian disimpan di rumah Supriyono warga Dusun Kauman, Desa Ngrundul, Kecamatan Kebonarum, Klaten, Jawa Tengah.

Tulisan dalam lingga tersebut terpahat melingkar sebanyak 3 baris dengan ukuran huruf $\pm 4 \mathrm{~cm}$, pemahatan tidak rata, kadang ada huruf yang terpahat besar dan kecil. Bagian atas lingga (tepi sudut atas) telah aus. Beberapa huruf di bagian itu telah hilang namun masih dapat diperkirakan pahatan hurufnya. Hasil 
pembacaan yang dilakukan oleh Goenawan A Sambodo, salah satu anggota Komunitas Kandang Kebo yang memiliki spesialisasi epigrafi adalah sebagai berikut:

“(s)wasti çāka wa(r)șāti(ta) 769 phalgu(ṇa ma)sa. tithi pratipāda krșnapakșa. pa.pā.çu. wāra. tatkāla say pamgĕt añgĕhan manusuk simma."

Lebih lanjut Goenawan juga melakukan alih bahasa ke dalam bahasa Indonesia yaitu berbunyi:

"selamat(lah) tahun çāka yang telah berjalan 769, pada bulan Phalguna, tanggal 1 paro gelap, di hari Paniruan, Pāhin, Çukra, ketika say pamgĕt añgĕhan membatasi sima". Atau hari Paniruan, Jumat Pahing, 18 Maret 847 M."

Tidak diketahui nama desa atau wilayah yang ditetapkan sebagai sima.

Pada kesempatan terdahulu, R. Goris pernah membaca lingga prasasti temuan dari dukuh Klorok, desa Ksatrian, Kecamatan Gayamprit, Klaten yang termuat dalam OV. 1928 hal 63-70, dan dimuat ulang dalam Berita Penelitian Arkeologi no 37 tahun 1986 hal 27-28. Hasil bacaan Goris atas prasasti lingga tersebut "hampir" mirip dengan bacaan pada prasasti lingga di Dusun Kauman ini. Perbedaan pokok adalah pada pembacaan angka tahunnya. Temuan lingga Gayamprit bacaan Goris memuat angka 756 Ç2. Berkenaan dengan penggunaan lingga bertulis sebagai penanda penetapan sima, terdapat istilah "srandu". Srandu adalah "garis maya" yang apabila saling dihubungkan dapat menunjukkan luasan sebuah daerah yang dibatasi. Atas dasar ini, sangat dimungkinkan adanya lingga patok bertulis lain yang sama di tempat lain.

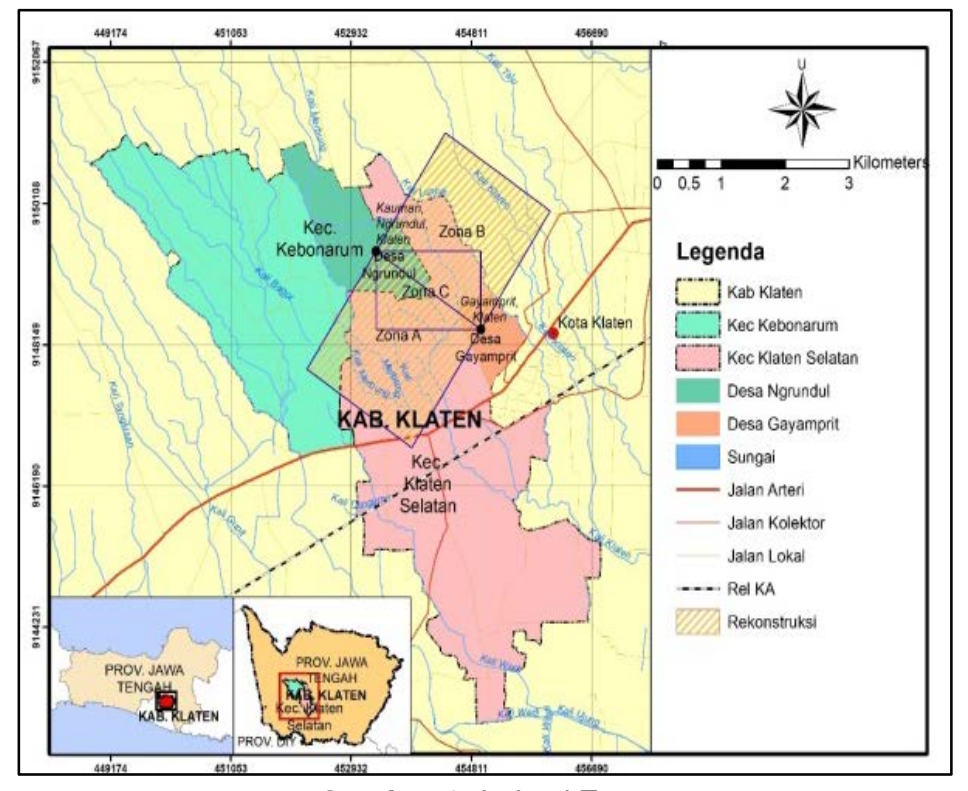

Gambar 2. Lokasi Zona

(Sumber: Hasil Rekonstruksi Oleh Tim Peneliti)

Berdasar diskusi antara Goenawan A Sambodo dan anggota Komunitas Kandang Kebo yang lain didapatkan suatu analisa cukup menarik. Berdasarkan kedua titik tersebut, dilakukan upaya rekonstruksi digital pada peta, dan

${ }^{2}$ Damais membaca angka tahunnya 796 Ç, sementara Bosch, membaca angka tahunnya 856 Ç 
menjadikan kedua titik tersebut sebagai titik tolaknya, baik sebagai titik utama sumbu panjang bidang persegi, maupun titik utama sumbu diagonal bidang persegi panjang. Hasil rekonstruksi digital peta tersebut membentuk Zona A, B, dan C, seperti terlihat pada peta di Gambar 2.

Zona-zona yang didapatkan dari proses rekonstruksi dibagi menjadi 3 zona.

\section{Zona A}

Zona A didapatkan dengan menghubungkan antara titik 1, yaitu Dusun Kauman, Desa Ngrandul, Kecamatan Kebonarum dengan titik 2, yaitu Desa Gayamprit, Kecamatan Klaten Selatan. Zona ini merupakan bidang persegi yang mempunyai sisi yang didapatkan dari menghubungkan kedua titik tersebut ke arah Barat Daya, dengan luasan sekitar 386,12 Ha. Adapun panjang masing-masing garis pada Zona ini adalah berkisar sepanjang 1,96-1,97 km.

\section{Zona B}

Zona B didapatkan dengan menghubungkan antara titik 1, yaitu Dusun Kauman, Desa Ngrandul, Kecamatan Kebonarum dengan titik 2, yaitu Desa Gayamprit, Kecamatan Klaten Selatan. Zona ini merupakan bidang persegi yang mempunyai sisi yang didapatkan dari menghubungkan kedua titik tersebut ke arah Timur, dengan luasan sekitar 386,14 Ha. Adapun panjang masing-masing garis pada Zona ini adalah berkisar sepanjang 1,96-1,97 km.

\section{Zona C}

Zona C didapatkan dengan menghubungkan antara titik 1, yaitu Dusun Kauman, Desa Ngrandul, Kecamatan Kebonarum dengan titik 2, yaitu Desa Gayamprit,

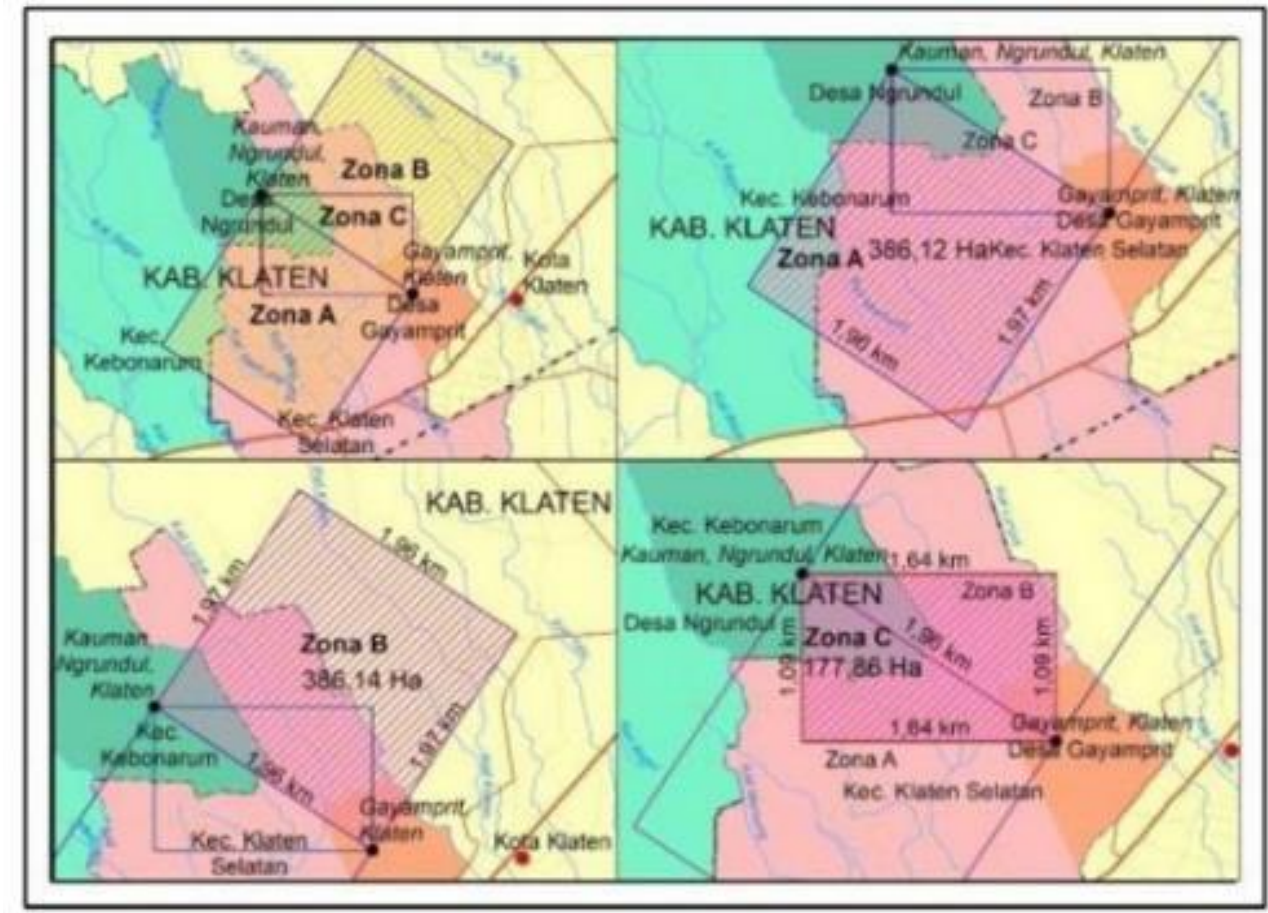

Gambar 3. Peta luasan masing-masing zona dan panjang garis rekonstruksinya. (Sumber: Hasil Rekonstruksi Oleh Tim Peneliti)

Peran Komunitas dalam Penanganan Temuan Baru Prasasti 
Kecamatan Klaten Selatan. Zona ini merupakan bidang persegi panjang yang didapatkan dari diagonal yang menghubungkan kedua titik tersebut, sehingga relatif beraksis timur-barat. Zona ini mempunyai luasan sekitar 177,86 Ha. Adapun panjang masing-masing garis pada Zona ini adalah berkisar sepanjang $1,09 \mathrm{~km}$ pada aksis utara-selatan, sepanjang 1,64 km pada aksis timur-barat, dan sepanjang 1,96 km pada diagonalnya. Luasan masing-masing zona dan panjang garis rekonstruksinya, bisa dilihat pada Gambar 3.

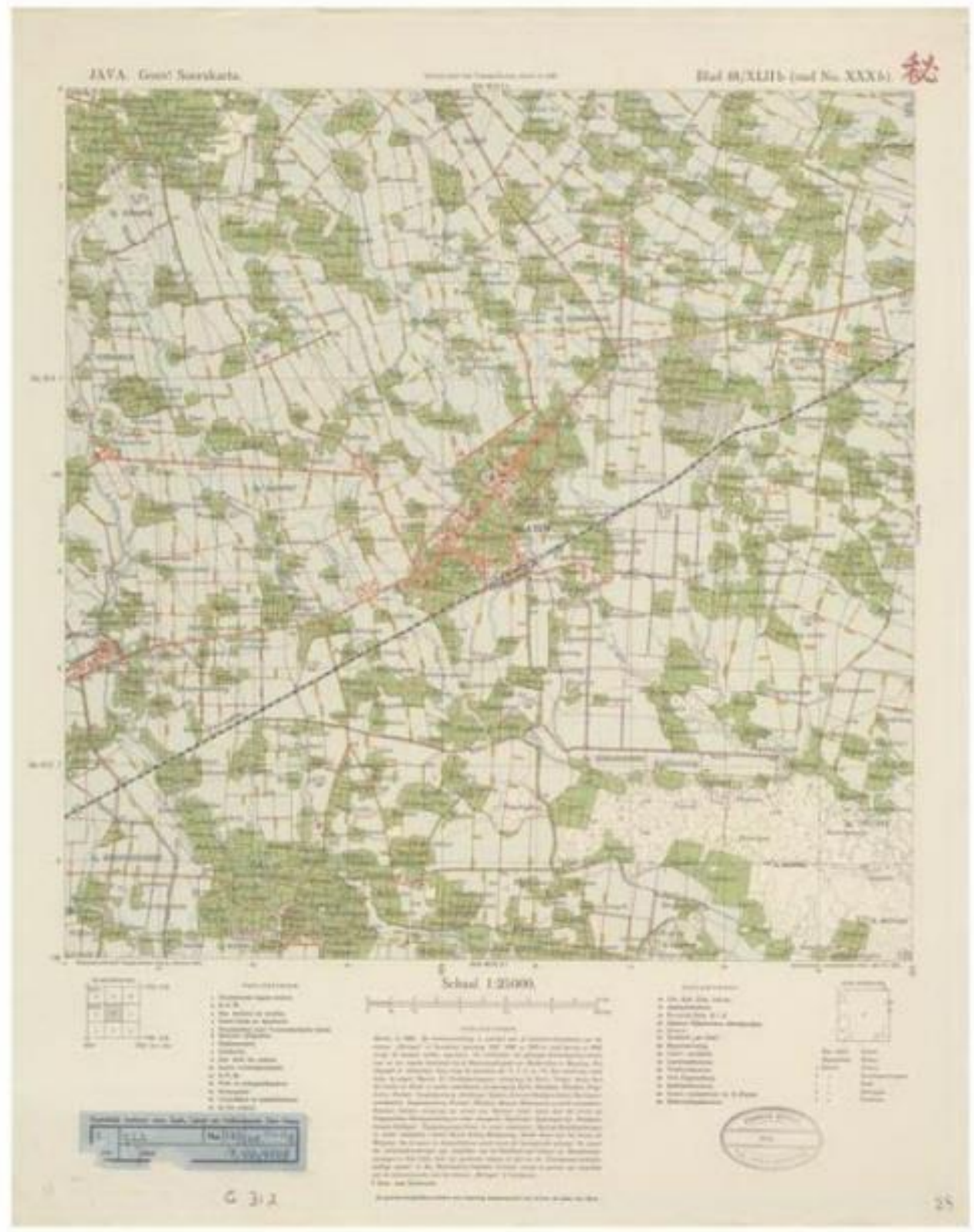

Gambar 4. Peta Lama Klaten Tahun 1930

(Sumber: http://maps.library.leiden.edu) 


\section{Rekonstruksi Toponimi}

Salah satu metodologi untuk mengetahui keberadaan benda cagar budaya (BCB) adalah dengan merunut pada catatan naskah kuna, termasuk dengan tafsir yang terkait. Pada naskah maupun tafsir tersebut tidak jarang didapatkan nama lokasi tempat keberadaan BCB pada masa lampau. Pada kasus ini, dilakukan perunutan untuk merekonstruksi toponimi lama dari peta lama (oude kaart) yang didasarkan pada Peta Klaten tahun 1930 yang dikeluarkan oleh Topografischen Dienst tahun 1930 yaitu Blad 48/XLIIb (oud no. XXXb) yang merupakan turunan dari lembar Peta Blad 48/XLI o. pada tahun yang sama, seperti terlihat pada Gambar 4. berada pada District Klaten, Regentschap Klaten, Residentie (Afdeling) Klaten.

Langkah selanjutnya, dilakukan tumpang susun (overlay) peta hasil rekonstruksi dengan peta lama tersebut, sehingga didapatkan hasil bahwa:

1. Titik 1, yang saat ini berada di Dusun Kauman, Desa Ngrundul, Kecamatan Kebonarum, dulunya adalah berada di Desa Setrijan;

2. Titik 2, yang saat ini berada di Desa Gayamprit, Kecamatan Kebonarum, dulunya adalah berada di Desa Gayamprit.

Sehingga sebagai kesimpulan hal ini selaras dengan tulisan R. Goris terhadulu pada OV tahun 1928 yang menyebutkan nama desa sima sebagai Dukuh Klorok, Desa Ksatrian, Kecamatan Gayamprit, Klaten.

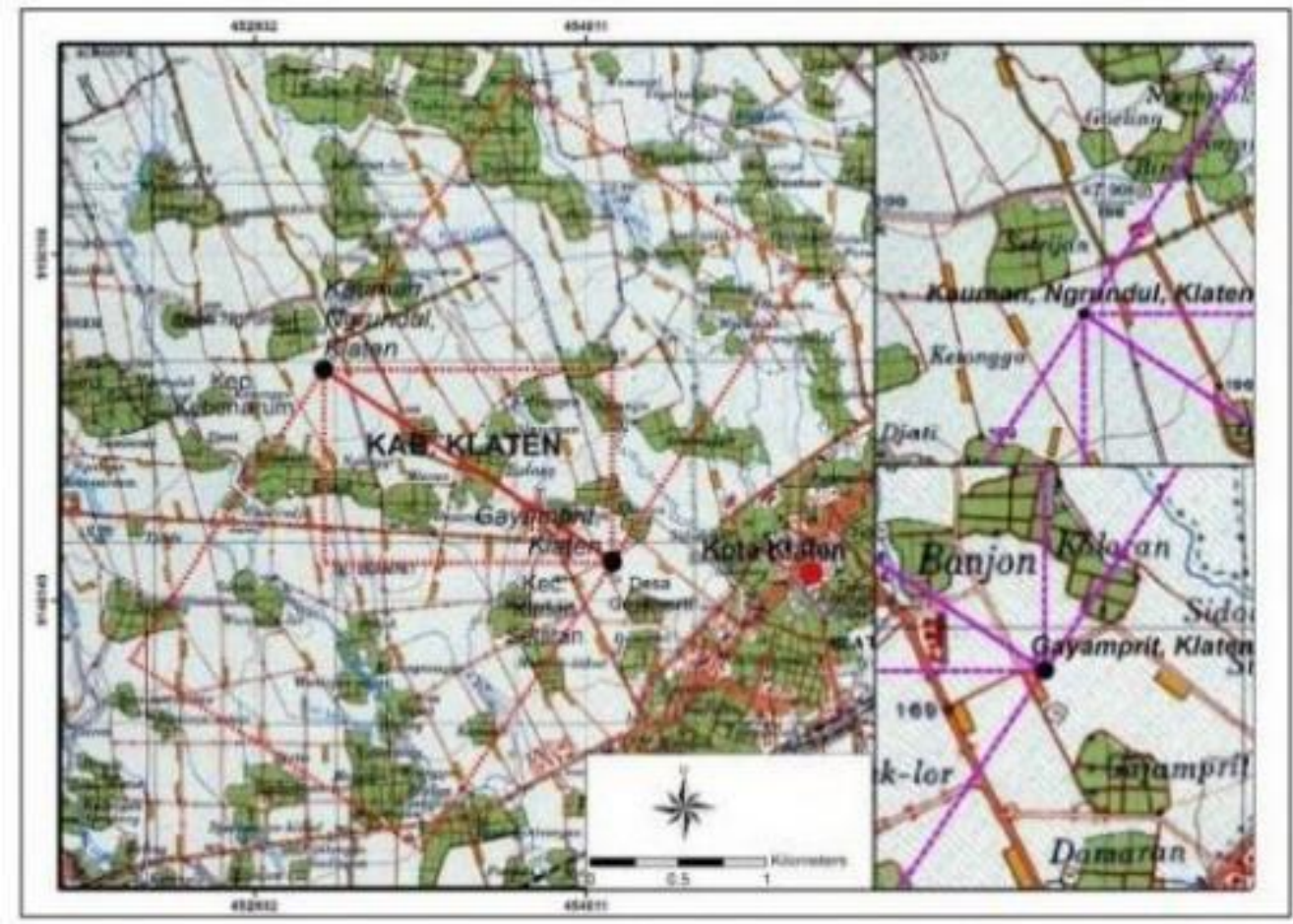

Gambar 5. Peta Hasil Tumpang Susun (Overlay) Dengan Peta Lama Tahun 1930 (Sumber: Hasil Rekonstruksi Oleh Tim Peneliti) 
Sebagai perbandingan, di Magelang pernah ditemukan 4 lingga prasasti berisi berita yang sama. Berita itu tentang penetapan sebuah wilayah menjadi sebuah sima. Tiga prasasti berisi tentang penanggalan dan pejabat yang melakukannya dan sebuah lagi, berisi tentang batas wilayah dan menyebut nama seorang raja (Sambodo, 2018, hlm. 72-84). Berdasarkan fakta tersebut maka dapat disimpulkan kemungkinan adanya kaitan antara Prasasti yang berada di Kauman dengan prasasti yang ditemukan di Gayamprit. Jika mengacu pada prasastiprasasti di Magelang, maka seharusnya terdapat dua prasasti lagi yang belum diketahui keberadaannya.

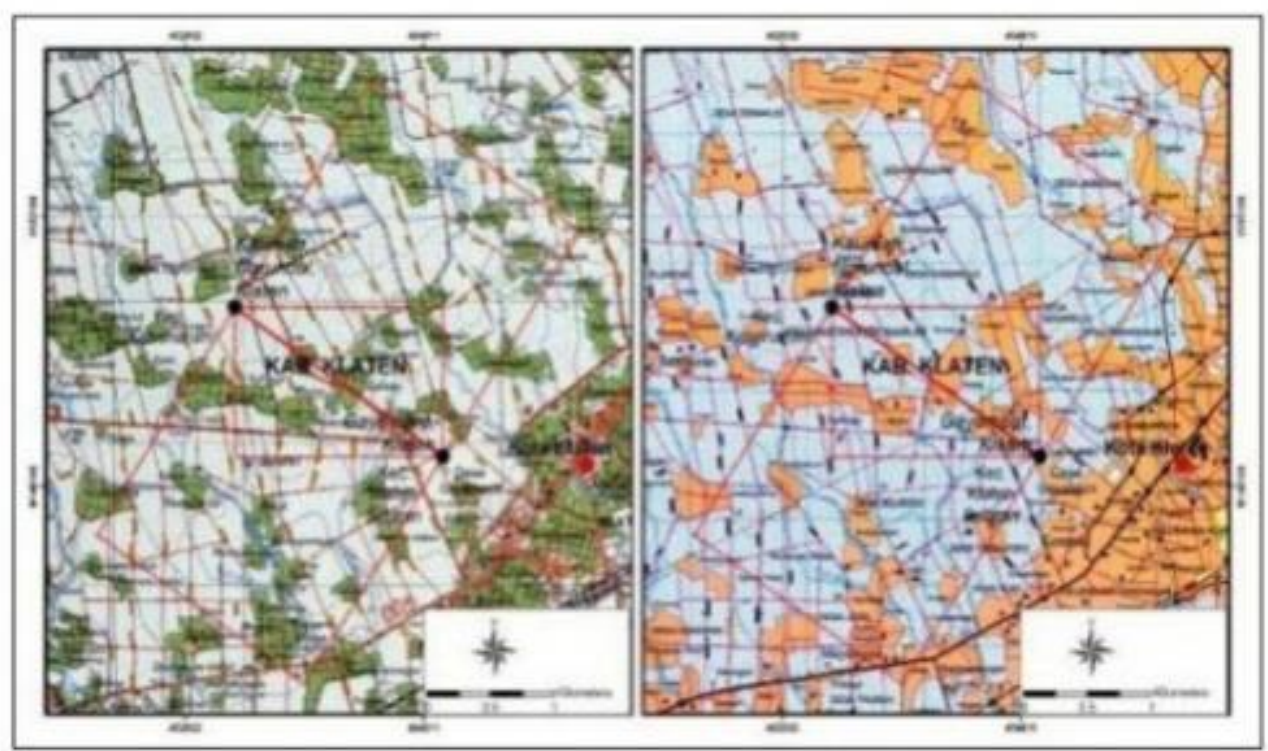

Gambar 6. Perbandingan Klaten Tahun 1930 Dengan Tahun 2001 (Sumber: Hasil Rekonstruksi Oleh Tim Peneliti)

\section{Lingga Bertulis di Kuburan Desa Baturono}

Sebuah lingga prasasti diinformasikan berada di sebuah pemakaman di desa Baturono, Ngluwar, Magelang, oleh teman-teman komunitas. Foto yang dikirimkan terlihat sebaris pahatan huruf jawa kuna dengan gaya pahatan abad 8$9 \mathrm{M}$, berbunyi "Pakihūnjạ" Batu itu dijadikan nisan penanda kubur dengan lingga patok lain yang tanpa tulisan. Lingga patok tersebut berukuran tinggi total sekitar $35 \mathrm{~cm}$ dengan diameter $17 \mathrm{~cm}$, bagian dasar yang berbentuk segi empat panjang memiliki total panjang $29 \mathrm{~cm}$ dan lebar $18 \mathrm{~cm}$. Pakihūjjah adalah sebuah penggalan mantra yang biasa didaraskan oleh para pendeta Buddha. Informasi lain tentang lingga bertulis "Pakihūnjah" juga didapatkan dari teman-teman komunitas di Klaten berada di pemakaman dukuh Cetok desa Baturan kecamatan Gantiwarno, kabupaten Klaten. Disebutkan ada sebuah lingga bertulis melingkar yang melalui photo terbaca "ța ki hū jah $\square$ " dan "pa ki hūy jah $\square$ " dalam empat rangkaian mantra. dua mantra pertama terbaca "ța ki hūy jah $\square$ " dan dua yang lain terbaca "pa ki hū jah $\square$ ". Kemungkinan maksud ke empat tulisan itu adalah "ța ki hū jah $\square$ " karena huruf "ța" dan "pa" agak sulit dibedakan dengan ukuran 
tinggi total $60 \mathrm{~cm}$, Bidang persegi $23 \times 23 \mathrm{~cm}$, diameter $22 \mathrm{~cm}$. Saat ini lingga disimpan di kantor BPCB Jateng.

Masih dari kabupaten Klaten, tepatnya di Dukuh Ngrundul Desa Ngrundul kecamatan Kebonarum, diinformasikan juga adanya sebuah lingga bertulis "pa ki hū jah $\square$ " berada di halaman rumah penduduk. Tidak diketahui berapa ukuran pasti benda ini karena pembacaan yang dilakukan hanya berdasarkan photo yang dikirimkan oleh teman komunitas. Meskipun prasasti prasasti tersebut tidak bertanggal ataupun bertahun, namun dari bentuk pahatan hurufnya masih dikenali berasal dari abad 8-9 M.

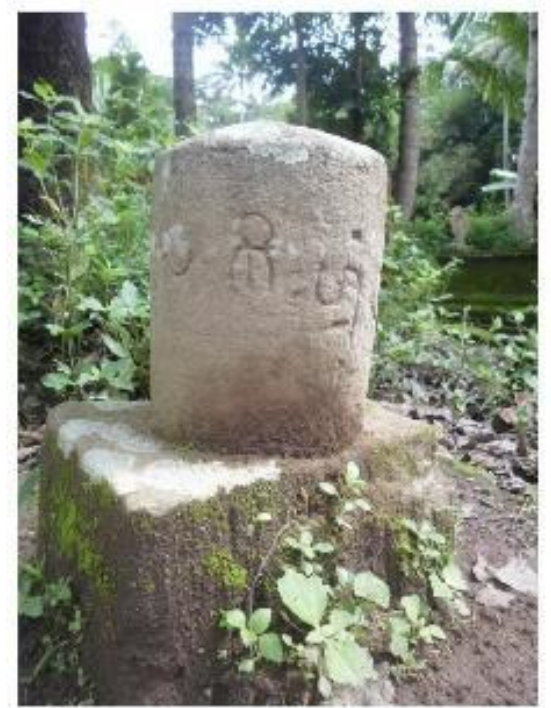

Gambar 7. Lingga Patok bertuliskan "Pakihunjah" dari Magelang

(Sumber: Goenawan A. Sambodo)

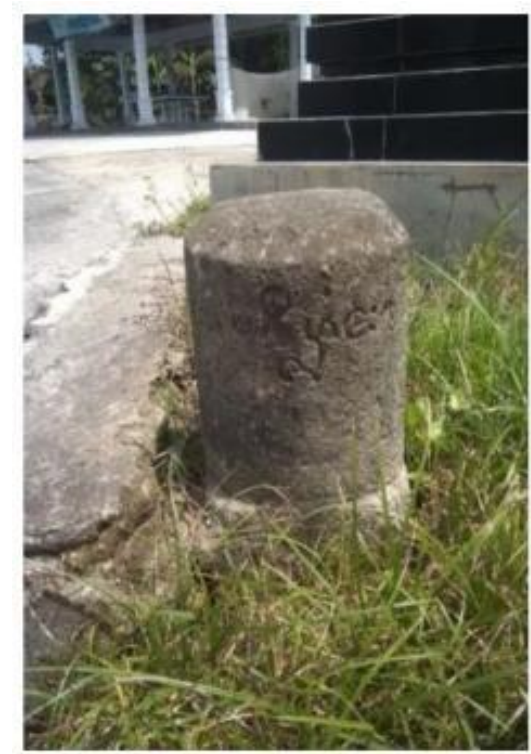

Gambar 8. Lingga Patok bertuliskan "Pakihunjah" dari Klaten

(Sumber: Koleksi Komunitas Kandang Kebo)

Menurut Vademekum Benda Cagar Budaya 2011, Lingga adalah Lambang dewa Siwa dalam agama Hindu. Lingga terdiri atas tiga bagian, yaitu bagian dasar berupa segi empat disebut brahmabhaga, bagian tengah berbentuk segi delapan disebut wisnubhaga dan bagian puncak berbentuk bulat panjang disebut siwabhaga. Walaupun jarang ditemukan, pada lingga acapkali dipahatkan juga wajah dewa Wisnu, Brahma, Siwa, atau dewa-dewa lain yang berhubungan dengan pemujaan Siwa. Jumlah wajah yang dipahatkan, lingga dapat dibedakan atas lingga ekamukha, berwajah satu; lingga dwimukha, berwajah dua; lingga trimukha, berwajah tiga; atau lingga caturmukha, berwajah empat (Djubiantoro, 2011, hlm. 22).

Pada umumnya tulisan mantra, tertulis pada media yang lebih kecil dan mudah dibawa seperti, lembaran emas (temuan dari Boko), lembaran tembaga, namun kadang disinggung pada kalimat kalimat yang ada dalam prasasti (lingga bertulis koleksi musnas no D.83 temuan dari Temanggung. OJO CIX). Ada pula mantra buddha yang tertulis pada sebuah lingga dengan kalimat yang cukup panjang, seperti yang pernah ditemukan di Kali Tirto, Berbah, Sleman (photo OD- 
21153 - 21160) berisi rangkaian mantra yang biasa di ucapkan para yogin dalam praktek ritual pemujaannya (Griffiths, 2014, hlm. 169)

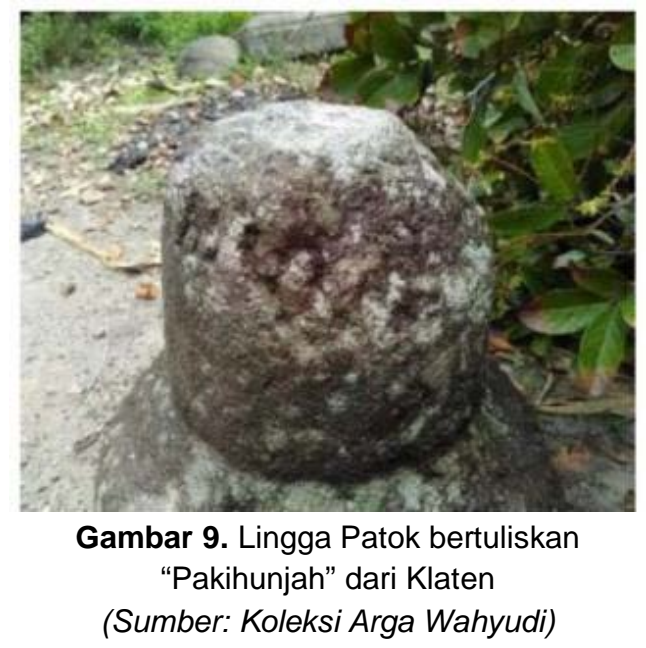

Jeffrey Roger Sundberg (2003, hlm. 166-170) seorang peneliti tentang Buddhism menemukan contoh mantra mantra yang mirip yakni takki hū jah, țakkijjah hun dalam teks teks tantra berbahasa Sanskerta, Tibet, dan Sino. Selain itu Sundberg juga menunjukkan bahwa dalam Sarva-tathāgata-tattva-sangraha (STTS) dalam bahasa Sansekerta mantra muncul dalam konteks mitos Trailokyawijaya Buddhis atau 'Penaklukan Maheśvara' oleh Bodhisattva Vajrapāṇi, sedangkan dalam sumber-sumber Sino-Jepang dikaitkan dengan penaklukan Aizen atas İśwara and Nārāyaṇa.

Kisah penaklukan seperti terdapat dalam Sarva-tathāgata-tattva-sanggraha (STTS) dapat dikisahkan sebagai berikut, berawal di puncak Gunung Mahameru, Wajrapani diminta untuk memanggil semua mahluk guna berlindung dengan Buddha, Dharma, Samgha, sehingga akan memperoleh pengetahuan Sang Buddha. Tersebutlah Maheswara (Siwa) yang belum mau tunduk. Kemudian Wairocana mengucapkan mantra hum takkijjah, yang dikenal sebagai mantra semua Tatagatas (sarvatathagata) untuk membuat Mahakala/para musuh menjadi tunduk dengan tongkat pelatih gajah. Dengan mantra ini, Maheswara (Siwa), dan semuanya diseret ke Istana Permata Adamantin di puncak Gunung Sumeru. Wairocana mencoba untuk campur tangan, untuk membujuk Maheswara dan seluruh dewa dari Dunia Tiga, namun Maheswara mengabaikan Wairocana. Akhirnya Maheswara memutuskan untuk mengintimidasi Wajrapani dengan mengambil bentuk Mahabhairawa yang menakutkan. Wajrapani tidak gentar dengan bentuk itu. Sembari mengucap mantra, iapun dapat mengalahkan Maheswara. Wairocana dengan sikap welas asihnya meminta Wajrapani untuk menghidupkan kembali Maheswara. Setelah dihidupkan kembali, Maheswara bukannya berterima kasih, namun meskipun dalam keadaan yang masih lemah, Maheswara kembali mengambil bentuk Maharudra yang menakutkan. Sekali lagi dengan mantra Wajrapani menundukkan Maheswara. Akhirnya Wajrapani menjadikan Maheswara dan Uma istrinya sebagai tempatnya berpijak.

Wairocana sekali lagi dengan sifat welas asihnya mengucapkan mantra yang merangkum Belas Kasih Semua Buddha untuk menolong Maheswara. 
Telapak kaki Wajrapani membawa kebebasan bukannya penderitaan. Dengan demikian tubuhnya jatuh di kaki Wajrapani. Maheswara terlahir kembali sebagai Tathagata disebut Bhasmeswaranirghosa di alam semesta yang dikenal sebagai Bhasmacchatra, yang ada jauh di bawah, di luar sistem dunia yang tak terhitung jumlahnya (Sundberg, 2003, hlm. 167-170)

\section{Prasasti dari Batu Alam dari Wonosegoro}

Berawal dari threat tentang sebuah batu alam bertulisan di wilayah Boyolali dalam group Facebook yang beberapa anggota Komunitas Kandang Kebo juga menjadi anggota group tersebut, maka keesokan harinya informasi tersebut segera dilaporkan kepada BРCB Jateng untuk di tindak lanjuti. Temuan batu alam bertulis itu diketahui berasal dari dusun Wonosegoro, desa Cepogo, kecamatan Cepogo, kabupaten Boyolali. Photo yang beredar, memperlihatkan tulisan yang menggunakan huruf Jawa kuna abad 8-9 M yang terpahat dalam 3 baris. Pembacaan awal berdasar photo yang kemudian dilanjutkan dengan pembacaan langsung di lokasi oleh Goenawan terbaca :

"swasti çāka warșātìta 823 jyașta māsa, pañcami çukla ha.wa.so. kāla niki paçarūnga nāma ...." .3.

berarti "selamat(lah) tahun çāka yang telah berjalan 823, pada bulan jyașța, tanggal 5 paro terang, hari Haryang, Wagai, Soma, ketika pertapaan di çarünga yang bernama...tanggal 5 paro terang, hari Haryang, Wagai, Soma, bulanjyașta, tahunçāka 823, setara dengan tanggal 25 Mei 901.

Menilik tahun yang ada, prasasti ini berasal dari masa pemerintahan raja

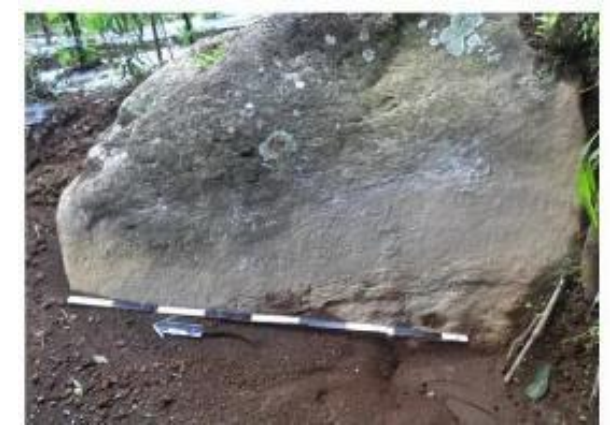

Gambar 10. Batu Alam Bertulis dalam Tiga Baris

(Sumber: Koleksi Goenawan A.Sambodo)

Balitung. Prasasti ini menjadi sangat menarik untuk dikaji lebih lanjut, karena penulisan kalimat-kalimat pendek seperti ini biasanya lebih banyak ditemukan di daerah Jawa Timur. Hasil penelitian Yogi Pradana (2017, hlm. 57), anggota komunitas Kandang Kebo menyimpulkan, dalam masa pemerintahan Raja Balitung, keberadaan tempat dan bangunan keagamaan tidak hanya dibuat atas perintah dari Śrī Maharājā sebagai penguasa tertinggi, para pejabat di tingkat lebih rendah seperti tingkatan daerah watak juga dapat melakukan kebijakan pelestarian bangunan keagamaan. Berdasarkan asumsi tersebut, sangat dimungkinkan,

${ }^{3}$ Goresan 3-4 kata terakhir tidak begitu jelas terlihat karena ada semacam kerak yang diduga merupakan proses awal pelapukan batu. 
bahwa pertapaan yang disebut dalam prasasti ini adalah salah satu dari bukti yang tertulis bahwa pejabat di bawah Śrī Maharājā dapat membuat kebijakan atau mengeluarkan perintah. Tidak begitu jauh prasasti itu juga terdapat sisa sisa struktur candi di dekat sungai dan batuan batuan candi berelief yang ditemukan ketika penduduk menggali kubur dan ditumpuk di salah satu sudut pemakaman desa.

Berdasarkan temuan beberapa prasasti sekaligus pembacaannya yang semuanya dilakukan secara mandiri oleh anggota komunitas Kandang Kebo menunjukkan bahwa komunitas pun bisa melakukan kegiatan yang sebenarnya adalah wewenang instansi terkait. Apabila kegiatan-kegiatan komunitas tersebut bisa diakomodir dan dijalin kerjasama yang sinergis oleh instansi terkait bisa dipastikan akan semakin banyak cagar budaya, khususnya prasasti yang bisa terdata dan terdokumentasi. Tanggapan yang cepat oleh instansi terkait atas laporan temuan, tentunya menjadi harapan yang sangat besar dari masyarakat agar kelestarian cagar budaya semakin meningkat.

\section{KESIMPULAN}

Berdasarkan kajian yang telah dilakukan dapat disimpulkan bahwa Peran komunitas sangat besar dalam penanganan temuan prasasti baru, karena informasi tentang temuan baru dalam komunitas cepat sekali beredar. Akan tetapi hal itu juga harus diimbangi dengan upaya sosialisasi yang tepat sehingga informasi yang cepat beredar tersebut tidak malah berujung dengan hilangnya temuan temuan baru. Hal ini telah pula dilakukan Komunitas Kandang Kebo untuk melakukan perlindungan temuan prasasti baru adalah penjaringan informasi temuan baru baik melalui anggotanya, maupun melalui media. Informasi yang didapatkan tersebut kemudian dikonfirmasi kebenarannya. Selanjutnya meneruskan informasi tersebut ke instansi terkait dalam hal ini adalah Balai Pelestarian cagar Budaya (BPCB). Sebagai komunitas yang independen, kegiatan Komunitas Kandang Kebo dalam pembacaan prasasti dan pelaporan ke BPCB merupakan suatu kegiatan yang sangat dibutuhkan dalam penanganan temuan prasasti-prasasti baru. Beberapa prasasti yang pernah ditangani langsung oleh anggota komunitas Kandang Kebo yaitu:

a. Prasasti Angĕhan II, berisi tentang penetapan Sima

b. Lingga Bertulis di Kuburan Desa Baturono, berisi mantra Buddha

c. Prasasti dari Batu Alam Dari Wonosegoro menyebut tentang pertapaan.

Oleh karena itu maka pelibatan komunitas yang sebenarnya memiliki Sumber Daya Manusia yang mumpuni oleh instansi-instansi terkait, bisa sangat membantu penanganan temuan-temuan prasasti maupun temuan lain. Diharapkan di masa yang akan datang tidak ada lagi temuan prasasti yang terlambat penanganannya.

\section{UCAPAN TERIMA KASIH}

Terima kasih penulis ucapkan untuk semua teman-teman di komunitas Kandang Kebo serta Arga Wahyudhi, atas foto yang digunakan dalam Penelitian ini. 


\section{DAFTAR PUSTAKA}

Acri, A. (2016). “Once More on the 'Ratu Boko Mantra'; Magic, Realpolitik, and Bauddha- Śaiva Dynamics in Ancient Nusantara". -Chapter 13. Esoteric Buddhism in Mediaeval Maritime Asia hlm 323-348, Singapore, ISEAS Publishing.

Anonim. Diunduh dari https://kebudayaan.kemdikbud.go.id/ditsejarah/kongres-nasionalkomunitas-sejarah-dan-geliat-ekosistem-budaya-kampung-madu/ diakses 27 Feb 2019 jam 09.30 WIB

Bosch, FDK. (1925). Oudheidkundig Verslag, hlm 18-19. Weltevreden : Albrecht \& Co. 's-Hage, M.Nijhoff.

Crow, G., and Allan, G., (1994). Community Life: An introduction to local social relations. New York: Hemel Hempstead: Harvester Wheatsheaf.

Damais, L.Ch. (1952). I. Etudes d'Épigraphie Indonésienne, III 'Liste des Principales Inscriptions Datees de I'Indonsie. BEfEO 1952 Tome 46 №1, hlm 1-105. Hanoi : Paris Imprimerie Nationale.

Darmosoetopo, R. (2008) Penyepadanan tahun Saka ke tahun Masehi pada data tertulis. Makalah tidak diterbitkan.

DITPCBM. (2015). Prasasti-prasasti di Kalimantan Barat. Diunduh dari https://kebudayaan.kemdikbud.go.id/ditpcbm/prasasti-prasasti-dikalimantan-barat/2 27 Feb 2019 jam. 10.00 WIB

Djubiantoro, T. (2011). Vademekum Benda Cagar Budaya, Cetakan V. Jakarta: Departemen Pendidikan dan Kebudayaan,.

Goris, R. (1928). De Oud-javaansche Inscripties unit het Sri-Wedari Museum to Soerakarta. Oudheidkundig Verslag. 1928, hlm 63-70. Weltevreden : Albrecht \& Co. 's-Hage, M.Nijhoff.

Griffiths. A. (2014). Written traces of the Buddhist past: Mantras and Dharanis in Indonesian Inscriptions. Bulletin of the School of Oriental and Africans Studies 77 (01). 137--194. https://doi.org/10.1017/s0041977X14000056.

Indrawan, A., dan Ichsan A.S., (2014).

https://www.republika.co.id/berita/nasional/umum/14/05/03/n4zzx1prasasti-majapahit-hilang-masyarakat-minta-investigasi diakses 1 Maret 2019 jam. 14.25 WIB

Kertajaya, H. (2008). Arti komunitas. Jakarta: Gramedia Pustaka

Nastiti, TS. (2009). Kedudukan dan Peranan Perempuan dalam Masyarakat Jawa Kuna (Abad VIII-XV Masehi). Disertasi. Program Studi Arkeologi. Fakultas Ilmu Pengetahuan Budaya. Universitas Indonesia

Navvab, M., Bisegna, F., Gugliermetti, F. (2013)“Experiencing the Tangible Past through Virtual Reconstruction: Cultural Heritage of Buildings and their 
Environmental Boundaries"; Journal Archaeomatica, September 2013, IV (3). 3641. Roma, Italy : MediaGEO SOC COOP,.

Poerwadarminto, WJS. (1984). Kamus Umum Bahasa Indonesia. Jakarta: PN Balai Pustaka.

Pradana, Y. (2017). Kebijakan Penguasa Dalam Pelestarian Bangunan Keagamaan Pada Masa Pemerintahan Rakai Watukura Dyah Balitung (898-910 M). Amerta Berkala Arkeologi 35 (1), 47-59. Jakarta : Proyek Penelitian Purbakala, Dep P\&K.

Sambodo, GA. (2018). Lingga bertulis di kuburan desa. Penelitian Terkini Prasasti Indonesia.72-82. Yogyakarta : FIB, Universitas Gadjah Mada.

Sarwono, SW. (2015). Teori-Teori Psikologi Sosial. Jakarta: Rajawali Press.

Suhardono. (2014). Pengertian Peran. Diunduh dari http://ariftetsuya.blogspot.co.id/2014/04/pengertian-peran.html diakses 1 Maret 2019 jam 14.05 WIB

Sukmadinata, S. (2007). Metode Penelitian Pendidikan. Bandung: PT. Remaja Rosdakarya.

Sundberg, JR. (2003). A Buddhist mantra recovered from the Ratu Baka plateau; A preliminary study of its implications for Sailendra-era Java. Bijdragen tot de taal-, land- en volkenkunde 159 (1), 163-188, Leiden : Brill, https://doi.org/10.1163/22134379-90003755

Sutopo, HB. (2002). Metodologi Penelitian Kualitatif. Surakarta: Sebelas Maret University Press.

Undang-Undang Republik Indonesia Nomor 11 Tahun 2010 Tentang Cagar Budaya.

Vanina Delobelle. 2008. Corporate Community Management. www.vaninadelobelle.com. diakses 1 Maret 2019 jam 14.15 wib

Wenger, E. dkk. 2002. Cultivating Communities of Practice. Harvard Business School Press. 